\title{
Pengaruh Akupresur Lo4 (he kuk) dan Thai Cong terhadap Tingkat Nyeri Persalinan Kala I pada Ibu Bersalin
}

\author{
Anita \\ Jurusan Keperawatan, Politeknik Kesehatan Tanjungkarang, Indonesia \\ Email: anitabustami@yahoo.co.id
}

\begin{abstract}
The Effect of Acupressure Lo4 (he kuk) and Thai Cong on First Childbirth Pain Level in Maternity. The study of women in the first stage of labor using McGill Pain Questionnaire to assess pain found that $60 \%$ of maternity described pain due to uterine contractions was very severe (intolerable, unverable, extremely severe), $30 \%$ moderate pain. In multipara $45 \%$ of pain is severe, $30 \%$ is moderate pain, $25 \%$ is mild pain (Acute Pain Services (APS), 2007). The aim of this study was to determine the effect of acupressure on the level of labor pain at the first time in maternity. Type of quantitative research, research design Quasy experiment. The population of first-time maternity with a $4-6 \mathrm{~cm}$ opening numbered 45 women giving birth per month, a sample of 40 respondents. The one group pre - post-test research design with interventions with acupressure point combinations L04 (he kuk) and thai cong that were carried out during the first active phase was 4-6 for 40 times at the time of his joke. The results showed that the level of first stage pain in maternity before acupressure was 6.00, SD 1,219 and after acupressure was 5.05 SD 1,218, it was concluded that there was an acupressure effect on the level of labor pain ( $p$-value=0,000). The application of L04 (he kuk) acupressure and Cong Thai can reduce labor pain in the first stage active phase of opening 4-6.
\end{abstract}

Keywords: Acupressure, Labor pain

\begin{abstract}
Abstrak: Pengaruh Akupresur Lo4 (he kuk) dan Thai Cong terhadap Tingkat Nyeri Persalinan Kala I pada Ibu Bersalin. Studi pada wanita dalam persalinan kala I dengan memakai McGill Pain Questionnare untuk menilai nyeri didapatkan bahwa $60 \%$ bersalin melukiskan nyeri akibat kontraksi uterus sangat hebat (intolerable, unverable, extremely severe), $30 \%$ nyeri sedang. Pada multipara $45 \%$ nyeri hebat, $30 \%$ nyeri sedang, $25 \%$ nyeri ringan (Acute Pain Services (APS), 2007). Penelitian ini bertujuan untuk mengetahui pengaruh akupresur terhadap tingkat nyeri persalinan kala I pada ibu bersalin. Jenis penelitian kuantitatif, rancangan penelitian Quasy eksperiment. Populasi ibu bersalin kala I dengan pembukaan 4-6 cm sejumlah 45 ibu bersalin perbulan, sampel sejumlah 40 responden. Rancangan penelitian one group pre-post test dengan intervensi akupresur kombinasi titik Lo4 (he kuk) dan thai cong yang dilakukan pada kala I fase aktif pembukaan 4-6 selama 40 kali pada saat his. Hasil penelitian diperoleh tingkat nyeri kala I pada ibu bersalin sebelum dilakukan akupresur adalah 6,00, SD 1,219 dan setelah diberikan akupresur adalah 5,05 SD 1,218, disimpulkan ada pengaruh akupresur terhadap tingkat nyeri persalinan ( $p$-value=0,000). Penerapan akupresur titik Lo4 (he kuk) dan thai cong dapat mengurangi nyeri persalinan pada ibu bersalin Kala I fase aktif pada pembukaan 4-6.
\end{abstract}

Kata kunci: Akupresur, Nyeri persalinan

Persalinan adalah proses fisiologis yang dinantikan ibu hamil untuk dapat merasakan kebahagiaan melihat dan memeluk bayinya. Persalinan juga disertai rasa nyeri yang membuat kebahagiaan yang didambakan diliputi oleh rasa takut dan cemas. Sebagian besar (90\%) persalinan disertai rasa nyeri sedang sampai berat (Saifuddin, 2016). Ibu muda di bawah umur 20 tahun atau yang di atas 35 tahun, pada saat persalinan ibu mengalami nyeri yang sangat hebat. Pada primipara, nyeri mulai dirasakan pada awal persalinan sedangkan pada multipara nyeri akan meningkat saat persalinan telah lanjut yaitu saat penurunan bagian terendah janin yang berlangsung cepat pada kala II (Yanti, 2010).

Studi pada wanita dalam persalinan kala I dengan memakai McGill Pain Questionnare untuk menilai nyeri didapatkan bahwa $60 \%$ primipara melukiskan nyeri akibat kontraksi uterus sangat hebat (intolerable, unverable, extremely severe), $30 \%$ nyeri sedang. Pada multipara $45 \%$ nyeri hebat, $30 \%$ nyeri sedang, 25\% nyeri ringan (Acute Pain Services (APS), 2007, dalam Damayanti, 2011). Nyeri persalinan 
dapat menimbulkan stres yang menyebabkan pelepasan hormon yang berlebihan seperti katekolamin dan steroid. Hormon ini menyebabkan ketegangan otot polos dan vasokonstriksi pembuluh darah. Hal ini mengakibatkan penurunan kontraksi uterus, penurunan sirkulasi uteroplasenta, pengurangan aliran darah dan oksigen ke uterus, serta timbulnya iskemia uterus yang membuat impuls nyeri bertambah (Saifudin, 2016).

Berbagai upaya dilakukan untuk menurunkan nyeri pada persalinan, tindakan dapat secara farmakologi maupun non farmakologi. Manajemen nyeri secara farmakologi lebih efektif dibanding dengan metode non farmakologi, namun metode farmakologi lebih mahal, dan memberikan efek yang kurang baik seperti adanya efek samping dari obat dan kadang obat tidak memiliki kekuatan efek yang diharapkan. Sedangkan metode non farmakologi lebih murah, sederhana, efektif, dan tanpa efek yang merugikan (Yanti, 2010).

Metode non farmakologi juga dapat meningkatkan kepuasan selama persalinan, karena ibu dapat mengontrol perasaan dan kekuatannya. Beberapa teknik non farmakologi yaitu, metode pernapasan, pergerakan dan perubahan posisi, massage, hidroterapi, terapi panas/dingin, musik, guided imagery, akupresur, aromaterapi merupakan tindakan yang dapat meningkatkan kenyamanan ibu saat bersalin dan mempunyai pengaruh pada koping yang efektif terhadap pengalaman persalinan (Yanti, 2010).

Akupresur merupakan salah satu teknik non farmakologi dalam manajemen nyeri persalinan. Akupresur berasal dari Cina yang telah ada sejak lima ribu tahun lalu dan merupakan kumpulan dari pengalaman dan penelitian dari abad ke abad yang dikembangkan sampai sekarang. Perkembangan akupresur tidak saja di negeri Cina, tetapi berkembang di Asia Timur sampai Eropa dan di Indonesia sudah ada sebelum perang dunia kedua, dan sampai saat ini lebih banyak berkembang di kalangan pengobatan tradisional karena merupakan pengobatan yang murah dan mudah (Khadka, 2011). Akupunturis atau ahli pengobatan Cina tradisional menyatakan memijat titik nyeri, efektif meredakan nyeri.

Akupresur berguna untuk bermacammacam sakit dan nyeri serta mengurangi ketegangan, kelelahan, dan penyakit. Dalam persalinan kala I akupresur dapat digunakan ketika kontraksi terasa nyeri. Nyeri ini muncul ketika terjadi blokade arus energi sepanjang meridian tertentu dalam tubuh. Blokade yang dilepaskan melalui teknik akupresur, keserasian dan fungsi akan kembali normal (Khadka, 2011). Akupresur memiliki keunggulan atau kelebihan dibandingkan dengan teknik atau metode lainnya. Akupresur sangat praktis karena tidak memerlukan banyak alat dan cukup dengan jari tangan, ibu jari, telunjuk, telapak tangan serta murah dan aman (Khadka, 2011).

Akupresur ini diketahui merangsang serat Ad yang masuk ke bagian dorsalis medula spinalis. Hal ini menimbulkan inhibisi segmental dari rangsangan nyeri yang dihantarkan oleh serat C yang berjalan lebih lambat, dan melalui koneksi di otak bagian tengah, menyebabkan inhibisi rangsangan nyeri pada serat $\mathrm{C}$ di bagian lain dari medula spinalis. Hal ini dapat menerangkan mengapa pijatan akupresur pada titik tertentu dapat menghilangkan sensasi nyeri di bagian lain dari tubuh. Dengan merangsang titik-titik tertentu di sepanjang sistem meridian, yang ditransmisi melalui serabut syaraf besar ke formatio reticularis, thalamus dan sistem limbik akan melepaskan endorfin dalam tubuh. Endorfin adalah zat penghilang rasa sakit secara alami diproduksi dalam tubuh, yang memicu respons menenangkan dan membangkitkan semangat di dalam tubuh, memiliki efek positif pada emosi, dapat menyebabkan relaksasi dan normalisasi fungsi tubuh. Sebagai hasil dari pelepasan endorfin, tekanan darah menurun dan meningkatkan sirkulasi darah (Alexander, 2001).

Penelitian Eko (2007), tentang perbedaan tingkat nyeri kala I pada ibu yang diberikan teknik akupresur dengan yang tidak diberikan akupresur, bahwa hampir semua responden pada kelompok eksperimen mengalami penurunan tingkat nyeri. Hasil studi pendahuluan di dua Rumah Bersalin di Bandar Lampung diperoleh data ibu bersalin rata-rata perbulan sejumlah 3045 ibu bersalin. Pemberian teknik akupresur Lo4 (he kuk) dan thai cong belum pernah dilakukan, pengurangan nyeri dilakukan dengan teknik nafas dalam dan massase pada lumbal 3-4 untuk memberikan kenyamanan pada saat persalinan. Tujuan penelitian untuk mengetahui "Pengaruh akupresur Lo4 (he kuk) dan thai cong terhadap tingkat nyeri persalinan kala I fase aktif pada ibu primipara di Rumah Bersalin Bandar Lampung”.

\section{METODE}

Jenis penelitian kuantitatif dan rancangan penelitian one group pre-post test. Populasi kasus yaitu seluruh ibu bersalin sejumlah 45 responden, sampel penelitian 40 ibu bersalin kala I dengan criteria inklusi persalinan kala I pembukaan 4-6 
cm,tempat penelitian di dua rumah bersalindi Bandar Lampung. Teknik pengambilan sampel accidental sampling. Pengambilan data diawali dengan penentuan kriteria, informed consent, pengukuran tingkat nyeri, intervensi akupresur Lo4 (he kuk) dan thai cong saat kontraksi, dilakukan saat kontraksi selama 60 menit perlakuan, setelah itu dilakukan pengukuran tingkat nyeri. Analisis data dengan uji $t$ dependent dengan tingkat kemaknaan 95\% ( $\alpha$ $0,05)$.

\section{HASIL}

Karakteristik ibu bersalin yang diberi akupresur di Rumah Bersalin Bandar Lampung tersaji pada tabel berikut.

Tabel 1. Distribusi Usia Ibu Bersalin

\begin{tabular}{lcccl}
\hline Variabel & Mean & Median & SD & Min-Max \\
\hline Usia & 28 & 29 & 3,947 & $21-35$ \\
\hline
\end{tabular}

Hasil analisis didapatkan rata-rata usia responden 28 tahun, tingkat nyeri kala I pada ibu bersalin sebelum diberi akupresur adalah 6 dengan SD 3,947. Tingkat nyeri persalinanterendah adalah 21 tahun dan yang tertinggi adalah 35 tahun.

Tabel 2. Distribusi Tingkat Pendidikan dan Pekerjaan Ibu

\begin{tabular}{lrr}
\hline \multicolumn{1}{c}{ Variabel } & Frekuensi & \% \\
\hline Pendidikan & & \\
SD-SMP & 8 & 20 \\
SMA-PT & 32 & 80 \\
\hline Pekerjaan & & \\
Ibu Rumah Tangga & 24 & 60 \\
Bekerja & 16 & 40 \\
\hline
\end{tabular}

Hasil analisis didapat ibu bersalin dengan pendidikan SMA dan pendidikan tinggi sejumlah $32 \mathrm{ibu}(80 \%)$, dan pekerjaan terbanyak ibu adalah ibu rumah tangga sejumlah 24 orang $(60 \%)$.

Tabel 3. Distribusi Tingkat Nyeri Kala I pada Ibu Bersalin Sebelum dan Setelah Tindakan Akupresur Lo4 (he kuk) dan Titik Thai cong

\begin{tabular}{lcccc}
\hline Tingkat Nyeri & Mean & Median & SD & Min-Max \\
\hline $\begin{array}{l}\text { Sebelum } \\
\text { akupresur }\end{array}$ & 6 & 5,05 & 1,219 & $3-8$ \\
\hline $\begin{array}{l}\text { Setelah } \\
\text { akupresur }\end{array}$ & 5 & 5,00 & 1,218 & $3-8$ \\
\hline
\end{tabular}

Hasil analisis didapatkan rata-rata tingkat nyeri kala I pada ibu bersalin sebelum diberi akupresuradalah 6 dengan SD 1,219. Tingkat Nyeri Persalinan terendah adalah 3 dan yang tertinggi adalah 8 . Hasil analisis didapatkan ratarata tingkat nyeri kala I pada ibu bersalin setelah diberi akupresur adalah 5 dengan SD 1,218.

Tabel 4. Pengaruh Akupresur Lo4 (he kuk) dan Titik Thai cong terhadap Tingkat Nyeri Persalinan Kala

\begin{tabular}{lrrrr}
\multicolumn{1}{c}{ Skala Nyeri } & Mean & SD & $\begin{array}{c}\boldsymbol{\rho} \\
\text { value }\end{array}$ & $\mathbf{n}$ \\
\hline Sebelum Akupresur & 6,00 & 1,219 & 0,000 & 40 \\
Setelah Akupresur & 5,05 & 1,218 & & 40 \\
\hline
\end{tabular}

Hasil penelitian diketahui bahwa rata-rata tingkat nyeri kala I pada ibu bersalinsebelum diberi akupresur adalah 6,00 dengan SD 1,219. Sedangkan rata-rata tingkat nyeri kala I pada ibu bersalin setelah diberi akupresur adalah 5,05 dengan SD 1,218, sehingga dapat disimpulkan bahwa ada pengaruh akupresur dengan tingkat nyeri persalinan kala I pada ibu bersalin. Hasil uji statistik didapatkan nilai $\rho=0,000$ ( $p$ hitung $<\alpha$ ), artinya pada $\alpha=5 \%$ dapat diartikan ada pengaruh akupresur dengan tingkat nyeri persalinan kala I pada ibubersalin di Rumah Bersalin Bandar Lampung.

\section{PEMBAHASAN}

\section{Distribusi Tingkat Nyeri Kala I pada Ibu Bersalin Sebelum Diberi Akupresur}

Hasil analisis didapatkan rata-rata tingkat nyeri kala I pada ibu bersalin sebelum diberi akupresurpada skala 6 dengan SD 1,219. Tingkat Nyeri Persalinan terendah adalah 3 dan yang tertinggi adalah 8. Saifudin AB (2016) mengemukakan bahwa nyeri yang dirasakan pada tiap individu pada kala I persalinan dapat berbeda dan berada pada rentang nyeri sedang dan nyeri hebat. Perasaan nyeri pada waktu his sangat subyektif, tidak hanya tergantung pada intensitas his tetapi juga tergantung pada keadaan mental ibu pada saat menghadapi persalinan. Keadaan mental ibu akan membuat ibu menjadi stres atau sebaliknya.

Banyak faktor penyebab nyeri persalinan diantaranya adalah stres dalam persalinan. Stres dapat menyebabkan nyeri yang sangat hebat saat persalinan karena stres memicu keluarnya hormon katekolamin dan adrenalin. Katekolamin ini akan dilepaskan dalam konsentrasi tinggi saat persalinan, rasa cemas dan takut pada ibu bersalin dapat menimbulkan berbagai respon tubuh. Akibat respon tubuh tersebut maka uterus 
menjadi semakin tegang sehingga aliran darah dan oksigen ke dalam otot-otot uterus berkurang karena arteri mengecil dan menyempit akibatnya adalah rasa nyeri yang tidak terelakkan. Dibutuhkan intervensi lebih lanjut agar tidak membahayakan ibu dan janin (Yanti, 2010).

Menurut Saifudin AB (2016) Nyeri viseral persalinan diakibatkan kontraksi uterus dan dilatasi serviks. Rasa nyeri ditransmisikan melalui aferen serabut saraf viseral, yang berjalan bersama serabut saraf simpatik dan memasuki spinal cord T-10, T-11, T-12 dan L-1. Nyeri somatik persalinan akibat turunnya janin mengakibatkan peregangan pelvis, vagina dan perineum, rasa nyeri ini ditransmisikan melalui saraf pudendal dan masuk pada cord S-2, S-3 dan S-4. Saraf pudendal memepersarafi vagina, vulva, perineum dan otot motorik pelvic floor.

Dalam penelitian ini respon nyeri yang dilakukan pada ibu bersalin kala I dengan pembukaan 4-6 dimana rasa nyeri persalinan masih dapat dikontrol oleh ibu bersalin. Skala nyeri yang dirasakan ibu bersalin sebelum diberikan akupresur yang paling ringan adalah 3 dan yang paling berat adalah 8. Nyeri yang dirasakan responden sebelum diberikan akupresur termasuk dalam kategori nyeri sedang sampai nyeri berat. Hal ini sesuai dengan teori yang mengatakan bahwa intensitas nyeri rata-rata pada ibu bersalin kala I fase aktif digambarkan dengan skala 6-7, dimana skala 6-7 merupakan kategori nyeri sedang sampai berat. Rasa nyeri yang dialami selama persalinan bersifat unik pada setiap ibu dapat dipengaruhi oleh beberapa faktor antara lain budaya, emosi, pengalaman persalinan, support system dan persiapan persalinan (Saifudin, 2016).

Rasa nyeri yang dialami ibu bersalin selama persalinan dapat muncul karena adanya kontraksi otot rahim, dimana kontraksi rahim menyebabkan dilatasi dan penipisan servik serta iskemia uterus. Dilatasi dan penipisan servik dapat menyebabkan terjadinya robekan jaringan selama kontraksi dan menyebabkan rasa takut yang memicu akifitas berlebih dari system saraf simpatis. Pada fase Laten lebih banyak penipisan, dimana penipisan tersebut disebabkan serviks membuka dan penurunan daerah terendah janin terjadi pada fase aktif dan transisi.

Pada kala I (fase dilatasi maksimal) dimulai dari pembukaan $4 \mathrm{~cm}$ sampai $9 \mathrm{~cm}$ ibu akan merasakan nyeri sedang sampai nyeri berat. Nyeri tersebut berasal dari bagian bawah abdomen dan menyebar ke daerah lumbal punggung dan menurun ke paha.Ibu biasanya mengalami nyeri hanya selama kontraksi dan bebas rasa nyeri pada interval antar kontraksi.
Hasil penelitian berada pada rentang nyeri ringan dan sedang, hal ini sesuai dengan teori bahwa nyeri yang dialami pada kala I pembukaan 4-6 berada pada skala nyeri sedang sampai berat.

\section{Distribusi Tingkat Nyeri Kala I pada Ibu Bersalin Setelah Diberi Akupresur}

Hasil analisis didapatkan rata-rata tingkat nyeri kala I pada ibu bersalin setelah diberi akupresur pada skala 5 dengan SD 1,218. Tingkat nyeri persalinan terendah adalah 3 dan yang tertinggi adalah 8. Akupresur diketahui dapat menurunkan nyeri persalinan dengan merangsang titik Lo4 (he kuk) dan thai cong, titik Lo4 (he $k u k$ ) dilakukan penekanan di antara ibu jari dan telunjuk pada bagian distal lipatan kedua jari dan arah gerakan melawan gerakan jarum jam. Sedangkan titik tekan thai cong dilakukan pada lipatan antara ibu jari dan telunjuk pada kaki. Titik tekan tersebut akan mentransmisi serabut syaraf besar ke formatio reticularis, thalamus dan sistem limbik sehingga dapat melepaskan endorphin yang berfungsi sebagai penghilang rasa sakit. Nyeri persalinan yang tidak diatasi secara adekuat mempunyai efek yang membahayakan diluar ketidaknyamanan yang disebabkannya, efek yang timbul tersebut akan mempengaruhi proses persalinan disamping akan memperburuk kondisi ibu dan janin, penurunan nyeri sesudah pemberian akupresur akan membantu ibu mengurangi ketidaknyamanan yang dirasakan karena nyeri persalinan tersebut. Nyeri persalinan dapat dikontrol dengan memberikan stimulus.

Salah satu stimulus tersebut adalah akupresur. Akupresur merupakan salah satu metode penanganan nyeri non farmakologis yang dapat diterapkan pada ibu bersalin. Maryunani (2010) mengemukakan bahwa nyeri saat persalinan dapat menimbulkan efek yang meliputi penderitaan, ketakutan, kecemasan, peningkatan kardiak output, tekanan darah, frekuensi nadi, penigkatan kadar plasma katekolamin, peningkatan kebutuhan oksigen, penurunan pengosongan lambung, inkoordinasi kontraksi uterus, penurunan aliran darah uteroplasenta dan asidosis akibat hipoksia pada janin.

Pemberian teknik akupresur pada ibu bersalin akan membantu untuk mengurangi nyeri persalinan yang dirasakan ibu. Rangsangan pada titik tangan Lo4 (he kuk) dan titik thai cong akan mendorong produksi endorfin dalam tubuh. Adanya endorfin dapat memicu respon menenangkan dan membangkitkan semangat dan memiliki efek positif pada emosi, sehingga dapat 
menyebabkan relaksasi dan normalisasi fungsi tubuh (Alexander, 2001).

\section{Pengaruh Akupresur Lo4 (he kuk) dan Titik Thai Cong terhadap Tingkat Nyeri Persalinan Kala I pada Ibu Bersalin}

Hasil penelitian diperoleh ada pengaruh akupresur dengan tingkat nyeri persalinan kala I pada ibu bersalin di Rumah Bandar Lampung ( $p$ value 0,000$)$. Hasil penelitian ini sesuai dengan penelitian Ikhtiarinawati \& Nuraini (2010), yang menyatakan bahwa ada pengaruh pemberian teknik akupresur terhadap penurunan tingkat nyeri persalinan kala I dengan uji statistik Wilcoxon Sign rank test menunjukkan $\mathrm{Z}=-4,491$ $p$-sign=0,000. Penelitian Rosdiantin, Maulana (2007) juga menyatakan bahwa ada pengaruh pemberian teknik akupresur (SPG1, KK31 dan LB36) terhadap tingkat nyeri inpartu kala I. Hasil penelitian ini juga memperjelas hipotesis Tournaire and Theau-Yonneau, (2007) yang menyatakan bahwa akupuntur poin memiliki sifat listrik yang jika dirangsang, dapat mengubah tingkat neurotransmitter di tubuh selain itu endorfin dilepaskan karena aktivasi dari rangsangan akupuntur. Hipotesis ini telah dibuktikan oleh Nanur (2014) yang melaporkan bahwa $58 \%$ perempuan dalam kelompok akupuntur tidak memerlukan anestesi selama persalinan, dibandingkan dengan $14 \%$ perempuan dalam kelompok kontrol. Akupresur merupakan penekanan pada titik akupuntur dengan menggunakan telunjuk maupun jari sehingga perangsangan dengan akupresur ini juga dapat mempengaruhi neurotransmitter di tubuh seperti halnya akupuntur (Tournaire and TheauYonneau, 2007).

Penelitian Hutagaol juga menyatakan bahwa terdapat pengaruh pemberian Teknik Akupresur terhadap Penurunan Nyeri Persalinan Kala I pada Ibu Primipara, dengan uji paired sample t-test diketahui bahwa intensitas nyeri sebelum dan setelah intervensi akupresur berbeda secara signifikan yaitu $p=0.000 \quad(p<0.05)$, diperoleh ada pengaruh teknik akupresur terhadap penurunan nyeri persalinan kala I pada ibu primipara.

Penelitian Nanur (2014) tentang Pengaruh Pemberian Teknik Akupresur Terhadap Nyeri Persalinan Kala I Fase Aktif Di RSUD Ambarawa 2013. Penelitian ini menjelaskan ada pengaruh pemberian teknik akupresur terhadap nyeri persalinan kala I fase aktif di ruang Bersalin RSUD Ambarawa Kabupaten Semarang, dengan nilai $p=0,0001(\alpha=0,05)$.
Berdasarkan uraian teori dan penelitian terkait memperjelas bahwa akupresur menunjukkan efektif dalam menurunkan intensitas nyeri persalinan kala I walaupun setiap penelitian menggunakan titik akupresur yang berbeda. Hal ini selaras dengan pernyataan Chung, L.,Hung, L., Kuo, S., Huang, C. (2003) bahwa banyak titik akupresur yang memiliki manfaat untuk menurunkan intensitas nyeri dan induksi persalinan.

Menurut Pillitteri (2003) rasa nyeri yang dialami selama persalinan memiliki 2 jenis menurut sumbernya yaitu nyeri visceral dan nyeri somatik. Nyeri visceral merupakan nyeri yang dirasakan ibu pada kala I. Impuls nyeri visceral ditransmisikan melalui segmen saraf spinal T1112 dan saraf simpatis lumbar bagian atas yang berawal dari dalam uterus dan serviks. Sehingga perangsangan pada titik akupresur dapat mengubah fungsi-fungsi fisiologis dari rahim karena titik ini merupakan saluran yang berjalan di dermatom bidang L5, L4, L2 dan L1, dan kemudian ke atas menuju T12 untuk T5.

Hal ini sesuai dengan teori gate control mengatakan bahwa impuls nyeri dapat diatur atau bahkan dihambat oleh mekanisme pertahanan disepanjang sistem saraf pusat. Teori "gate control" menggambarkan bahwa ada mekanisme gate terbuka pada ujungsaraf ruas tulang belakang (spinal cord) yang dapat meningkatkan atau menurunkan aliran impuls saraf dari serat perifer menuju sistem saraf pusat. Bila gate tertutup tidak ada nyeri dan bila gate terbuka ada nyeri. Dalam hal ini, rasa nyeri dikendalikan oleh aksi penghambatan pada jalur nyeri.

Akupresur Lo4 (he kuk) dan thai cong ini diketahui merangsang serat Ad yang masuk kebagian dorsalis medula spinalis. Hal ini menimbulkan inhibisi segmental dari rangsangan nyeri yang dihantarkan oleh serat $\mathrm{C}$ yang berjalan lebih lambat, dan melalui koneksi di otak bagian tengah, menyebabkan inhibisi rangsangan nyeripada serat $\mathrm{C}$ di bagian lain dari medulla spinalis. Pesan yang dihasilkan akan menstimulasi mekano reseptor, apabila masukan yang dominan berasal dari serabut delta Adan serabut C, maka akan membuka pertahanan tersebut dan klien mempersepsikan sensasi nyeri bahkan jika impuls nyeri dihantarkan ke otak, terdapat pusat kortek yang lebih tinggidi otak yang memodifikasi nyeri. Alur saraf desenden melepaskan opiate yaitu berupa endorfin, suatu pembunuh nyeri alami yang berasal dari tubuh. Hal ini dapat menerangkan mengapa pijatan akupresur pada titik tangan dan titik Lo4 (he kuk) dan thai cong dapat mengurangi nyeri persalinan. Dengan adanya rangsangan pada titik Lo4 (he 
kuk) dan thai cong. Titik antara ibu jari dan telunjuk pada tangan dan titik antara ibu jari dan telunjuk jari kaki dapat membantu pelepasan endorfin dalam tubuh.

Endorfin adalah zat penghilang rasa sakit secara alami diproduksi dalam tubuh, yang memicu respon menenangkan dan membangkitkan semangat di dalam tubuh, memiliki efek positif pada emosi, dapat menyebabkan relaksasi dan normalisasi fungsi tubuh. Sebagai hasil dari pelepasan endorfin, tekanan darah menurun dan meningkatkan sirkulasi darah.

\section{SIMPULAN}

1. Rata-rata tingkat nyeri kala I pada ibu bersalin sebelum diberi akupresur Lo4 (he kuk) dan thai cong adalah 6 dengan SD 1,219 .

2. Rata-rata tingkat nyeri kala I pada ibu bersalin setelah tidak diberi akupresur Lo4 (he kuk) dan thai cong adalah 5,05 dengan SD 0,91 .

3. Ada pengaruh akupresur Lo4 (he kuk) dan thai cong terhadap tingkat nyeri persalinan kala I pada ibu bersalin ( $p$-value $=0,000)$.

\section{DAFTAR PUSTAKA}

Alexander. 2011. Guidelines for the prevention of intravascular catheter- related infections. https://academic.oup.com/cid/article/52/9 /e162/319981.

Chung, L.,Hung, L., Kuo, S., Huang, C. 2003. Effects of LI4 and BL 67 Acupressure on Labor Pain and Uterine Contractions in the First Stage of Labor. Journal

Damayanti, D. R. E. 2011. Pengaruh Pemberian Teknik Akupresur Titik pada Tangan terhadap Nyeri Persalinan pada Ibu Intranatal Kala I di RSU PKU Muhammadiyah Bantul. [Skripsi], Yogyakarta: STIKES Aisyiyah.

Humenick, Nicholas, F.H. 2000. Childbirth Education: Practice, Research and Theory. Philadelphia: W.B. Saunders Company.

Hutagaol, I. 2007. Pengaruh Pemberian Teknik Akupresur terhadap Penurunan Nyeri Persalinan Kala I pada Ibu Primpara. https://www.researchgate.net/publication/ 47513339.

Ikhtiarinawati F, Nur Aini, R. 2010. Pengaruh Pemberian Teknik Akupresur terhadap

\section{SARAN}

1. Bagi Rumah Bersalin di Bandar Lampung Terapi akupresur sebagai salah satu alternatif penatalaksanaan non farmakologi terutama penekanan pada titik Lo4 (he kuk) dan thai cong pada asuhan keperawatan pada ibu bersalin dikarenakan sangat mudah dan dapat dianjurkan pada pendamping persalinan, sehingga kebutuhan rasa nyaman dapat terpenuhi.

2. Bagi pengembangan penelitian keperawatan selanjutnya

Pengembangan penelitian selanjutnya dapat dilakukan pembuktian keefektifan akupresur dalam mengatasi nyeri pada kasus nyeri menstruasi, atau nyeri pada kasus lain. Tindakan akupresur juga dapat diupayakan untuk meningkatkan kontraksi uterus pada hipotonik.

3. Bagi pengembangan ilmu keperawatan Penelitian ini dapat digunakan sebagai salah satu sumber evidence based dalam ilmu keperawatan khususnya keperawatan komplementer.

Tingkat Nyeri Persalinan Kala I. Jurnal Midpro, edisi 1 . https://media.neliti.com/media/publicatio ns/197137-ID-acupressure-ascomplementary-and-alterna.pdf.

Katz, J., \& Melzack, R. 2014. McGill Pain Questionnaire. Encyclopedia of Quality of Life and Well-Being Research, 38813883 .

Khadka, A., Liu, Y., Li, J., Zhu, S., Luo, E., Feng, G., \& Hu, J. 2011. Changes in quality of life after orthognathic surgery: a comparison based on the involvement of the occlusion. Oral Surgery, Oral Medicine, Oral Pathology, Oral Radiology, and Endodontology, 112(6), 719-725.

Maryunani. 2016. Manajemen Kebidanan Terlengkap. Jakarta: CV Trans info media.

Nanur, FN. 2014. Pengaruh pemberian teknik akupresur terhadap nyeri kala I fase Aktif di RSUD Ambarawa 2013. Prosiding Seminar Nasional \& Internasional (vol. 2, no. 2). 
https://jurnal.unimus.ac.id/index.php/psn 12012010/article/view/1427.

Pilliteri. 2003. Maternal and Child Health nursing Care of Childbearing and Childrearing Family. Philadelpia: William \& Wilkin.

Rosdiantin, IE, Maulana, D. 2007. Pengaruh Pemberian Teknik Akupresur terhadap Tingkat Nyeri Persalinan Kala I di RS Rajawali Citra Potorono Bantul. Seminar Nasional Teknologi.
Saifudin, A.B, 2016. Ilmu Kebidanan. Jakarta: Yayasan Bina Pustaka Sarwono Prawirohardjo.

Tournaire M., Theau-Yonneau, A. 2007. Complementary and Alternative to Pain relief During Labor. CAM 2007; 4(4),409-417. Advance accsess Publication 15 Maret 2007. http://www.creativecommons.org/license s/by-nc/2.o/uk/

Yanti. 2010. Buku Ajar Asuhan Kebidanan Persalinan.Yogyakarta: Pustaka Rihama. 